\title{
MONITORING FOR COMMERCIAL BROILER BREEDER FLOCKS AND THEIR PROGENY FOR MYCOPLASMA GALLISEPTICUM INFECTION AND PERFORMANCE AFTER VACCINATION WITH TS-11
}

\author{
GAMAL H.M.; IBRAHIM A.I. and OTHMAN N.M. \\ Dept. of Poultry Diseases, Faculty of Veterinary Medicine-South Valley University
}

Received: 27 July 2017; $\quad$ Accepted: 1 October 2017

\begin{abstract}
Monitoring and comparison of MG natural infection occurrence, vertical transmission, egg production and hatchability between same breed two sequential flocks in three broiler breeders farms were performed. The first flock in each farm used different $\mathrm{Mg}$ control programs as killed vaccines, antimycoplasmal drugs, live vaccine (F strain) or mixed program (as killed vaccine with antimycoplasmal drug) and the next flock in each farm used TS-11 program (Vaxsafe $\mathrm{MG}^{\mathrm{TM}}$, Bioproperities ${ }^{\circledR}$ ) administrated by eye drop at age of 3-4 weeks after performing ELISA test to ensure that flocks are free from MG antibodies before vaccination. MG natural infection occurrence and vertical transmission were assessed by PCR for detection of field strain in breeders lower trachea, ovaries and air sacs and their progeny clonal cavity and upper trachea. Egg production and hatchability were assessed by comparison of weekly production and hatchability with ideal breed production and hatchability catalog curves and curves of previous flocks used other programs for controlling MG.TS-11 gave better results counter to other MG control programs in all parameters where no natural infection or vertical transmission has been detected where all collected samples gave negative results for PCR except one sample in farm (A) and when repeating sampling and PCR test at 48 weeks old it gave negative result which explaining exposure to challenge but no infection occurs and performance was the best with TS-11 where production and hatchability was better and the differences were significant.
\end{abstract}

Key words: Mycoplasma gallisepticum, TS 11, Vaccination

\section{INTRODUCTION}

In Egypt Mycoplasma gallisepticum (MG) is the most economically significant mycoplasmas species in poultry industry. Mycoplasmas are among the most important egg-borne diseases in poultry industry. Spreading of infection in breeder and layer leads to high losses during the production cycle. It can be transmitted by both lateral and vertical routes (Ley, 2003).

The best approach for controlling mycoplasma is depopulation of the infected sites followed by cleaning and disinfection and 4-6weeks free period. This approach is very difficult and may be impossible in our country due to economic issues. So, practically, shifting from eradication to control is necessary. Control program depend on one of this after a diligent biosecurity: 1-Medication with antimycoplasmal drugs.2-Vaccination (Live, Killed vaccines and vector vaccines).

Corresponding author: Dr. GAMAL H.M

E-mail address: haytham.gamal@ift-online.com

Present address: Dept. of Poultry Diseases, Faculty of Veterinary Medicine-South Valley University
Medication using antimycoplasmal drugs including Macrolides, Tetracyclines and Flouroquinolonesis is useful (Ley, 2003). Killed vaccines (Oil emulsion) reduce infection but usually tracheal colonization by Mycoplasma gallisepticum after challenge with virulent strains occurs (Yagihashi et al., 1992). Live vaccine strains used for MG controlling are F. Strain, 6/85 and TS-11. F. Strain and 6/85 (originated from USA) and Ts-11(originated from Australia), are used for controlling of MG infection in several countries (Ley, 2008). Temperature sensitive mutant strains are able to colonize in the upper respiratory tract. They are not able to survive at the temperature of the lower tract and air sacs (Levisohn et al., 1987). Recombinant fowl pox virus - MG ( $\mathrm{Rfpv}-\mathrm{MG}$ ) is used for protection against MG and give better results when used with F. Strain (Pakpinyo et al., 2015).

PCR and recently real time PCR allows rapid detection of $\mathrm{MG}$ from cultures or directly from clinical samples (Callison et al., 2006).

TS-11 can't survive in temperature more than $33^{\circ} \mathrm{c}$ so samples taken from lower trachea, lung and air sacs help for direct detection of field MG without vaccinal strain detection. 


\section{Aim of study}

In Egypt many broiler breeder farms were exposed to MG infection which causes significant losses in egg production and hatchability in addition to transovarian transmission which badly affect the offspring performance despite using different available control programs. Newly introduced TS-11 MG live vaccine was a chance to evaluate it under field conditions in farms already have been exposed for infection for its efficacy for prevention of infection, prevention of vertical transmission and flocks performance.

\section{MATERIALS AND METHODS}

\section{Samples sources:}

Six flocks, of same breed and two sequential flocks in three broiler breeders farms

Three Farms data:

These have been coded (A,B and C) and each one of the two flocks in each farm was coded (TS AND O) as below:

ATS $=$ flock in farm A Vaccinated with TS-11

$\mathrm{AO}=$ flock in farm $\mathrm{A}$ use other program for controlling $\mathrm{MG}$

BTS $=$ flock in farm B Vaccinated with TS-11

$\mathrm{BO}=$ flock in farm $\mathrm{B}$ use other program for controlling $\mathrm{MG}$

CTS = flock in farm C Vaccinated with TS-11

$\mathrm{CO}=$ flock in farm $\mathrm{C}$ use other program for controlling $\mathrm{MG}$

Table 2.1: Showing data of the six flocks of the three farms.

\begin{tabular}{|c|c|c|c|c|c|c|c|c|}
\hline & & ATS & $\mathrm{AO}$ & BTS & $\mathrm{BO}$ & CTS & $\mathrm{CO}$ & NOTES \\
\hline $\begin{array}{l}\text { Date of } \\
\text { Housing }\end{array}$ & & $03 / 01 / 2015$ & $12 / 04 / 2013$ & $27 / 03 / 2015$ & $9 / 06 / 2013$ & $22 / 05 / 2015$ & $22 / 08 / 2013$ & \\
\hline \multirow{2}{*}{$\begin{array}{l}\text { No of } \\
\text { birds }\end{array}$} & $q$ & 20000 & 20000 & 30000 & 30000 & 20000 & 20000 & \\
\hline & $\pi$ & 3000 & 2600 & 4300 & 4000 & 2800 & 2500 & \\
\hline Breed & & $\begin{array}{l}\text { Cobb } 500 \\
\text { FF }\end{array}$ & $\begin{array}{c}\text { Cobb } 500 \\
\text { FF }\end{array}$ & $\begin{array}{l}\text { Cobb } 500 \\
\text { FF }\end{array}$ & $\begin{array}{c}\text { Cobb } 500 \\
\text { FF }\end{array}$ & $\begin{array}{c}\text { Cobb } 500 \\
\text { FF }\end{array}$ & $\begin{array}{c}\text { Cobb } 500 \\
\text { FF }\end{array}$ & \\
\hline Area & & $\begin{array}{l}\text { Alexandria } \\
\text { Desert road }\end{array}$ & $\begin{array}{l}\text { Alexandria } \\
\text { Desert road }\end{array}$ & Sharqia & Sharqia & Dakhlia & Dakhlia & \\
\hline
\end{tabular}

Table 2.2: Showing mycoplasma gallisepticum control program for the six flocks.

\begin{tabular}{|c|c|c|c|c|c|c|c|c|}
\hline & \multicolumn{2}{|c|}{ Vaccination } & \multicolumn{6}{|c|}{ Medication } \\
\hline & $\begin{array}{l}\text { Killed MG } \\
\text { vaccine }\end{array}$ & $\begin{array}{c}\text { Live } \\
\text { MG } \\
\text { Vaccine }\end{array}$ & 1st week & 4rd week & 8th week & 12 week & 16week & $\begin{array}{l}\text { From } 20 \text { week till } \\
\text { end of production }\end{array}$ \\
\hline ATS & & $\begin{array}{c}\text { TS-11 } \\
\text { at } 4 \\
\text { weeks }\end{array}$ & $\begin{array}{l}\text { Doxycycline } \\
+ \text { colistin }\end{array}$ & & & & & \\
\hline $\mathrm{AO}$ & $\begin{array}{cc}11 & 16 \\
\text { weeks } & \text { weeks }\end{array}$ & & $\begin{array}{l}\text { Antibiotic } \\
\text { combination }\end{array}$ & $\begin{array}{c}\text { Antimycoplasma } \\
\text { DW }\end{array}$ & $\begin{array}{c}\text { Antimycoplasma } \\
\text { DW }\end{array}$ & $\begin{array}{c}\text { Antimycoplasma } \\
\text { DW }\end{array}$ & $\begin{array}{c}\text { Antimycoplasma } \\
\text { In feed }\end{array}$ & $\begin{array}{c}\text { Antimycoplasma } \\
\text { In feed every 3-4 } \\
\text { weeks }\end{array}$ \\
\hline BTS & & $\begin{array}{c}\text { TS-11 } \\
\text { at } 6 \\
\text { weeks }\end{array}$ & $\begin{array}{l}\text { Doxycycline } \\
+ \text { colistin }\end{array}$ & & & & & \\
\hline $\mathrm{BO}$ & & $\begin{array}{c}\text { F strain } \\
\text { at } 8 \\
\text { weeks }\end{array}$ & $\begin{array}{l}\text { Antibiotic } \\
\text { combination }\end{array}$ & $\begin{array}{c}\text { Antimycoplasma } \\
\text { DW }\end{array}$ & & & $\begin{array}{c}\text { Antimycoplasma } \\
\text { In feed }\end{array}$ & $\begin{array}{c}\text { Antimycoplasma } \\
\text { In feed every 3-4 } \\
\text { weeks }\end{array}$ \\
\hline CTS & & $\begin{array}{c}\text { TS-11 } \\
\text { at } 3 \\
\text { weeks }\end{array}$ & $\begin{array}{l}\text { Doxycycline } \\
+ \text { colistin }\end{array}$ & & & & & \\
\hline $\mathrm{CO}$ & & & $\begin{array}{l}\text { Antibiotic } \\
\text { combination }\end{array}$ & $\begin{array}{c}\text { Antimycoplasma } \\
\text { DW }\end{array}$ & $\begin{array}{c}\text { Antimycoplasma } \\
\text { DW }\end{array}$ & $\begin{array}{c}\text { Antimycoplasma } \\
\text { DW }\end{array}$ & $\begin{array}{l}\text { Antimycoplasma } \\
\text { In feed }\end{array}$ & $\begin{array}{c}\text { Antimycoplasma } \\
\text { In feed every 3-4 } \\
\text { weeks }\end{array}$ \\
\hline
\end{tabular}

TS-11 vaccine $=$ Vaxsafe MG $^{\mathrm{TM}}$, Bioproperities ${ }^{\circledR}$ administrated by eye drop

Killed MG vaccine $=$ NOBILIS MG INACTM MSD ${ }^{\circledR}$

F.strain $=$ Cevac MG F TM, CEVA $\mathbb{R}$

Antimycoplasma DW = Tilmicosin or Tylosin

Antimycoplasma in feed $=$ Tylosin

TS-11 vaccine $=$ Vaxsafe MG $^{\mathrm{TM}}$, Bioproperities ${ }^{\circledR}$ administrated by eye drop, Killed MG vaccine $=$ NOBILIS MG INACTM MSD®, F.strain=Cevac MG FTM, CEVA ${ }^{\circledR}$, Antimycoplasma DW=Tilmicosin or Tylosin, Antimycoplasma in feed = Tylosin 


\section{Protocol of sampling}

A- Before vaccination, samples are Blood.

B-Six weeks post vaccination, samples are organs (Lower trachea, lung, air sacs and ovaries).

C-Prior to laying at 20 weeks of age, samples are organs (Lower trachea, lung, air sacs and ovaries).

D- At peak of production (30 weeks of age), samples are organs (Lower trachea, lung, air sacs and ovaries).

E- From progeny at peak of production (30 weeks of age), samples are Tracheal swabs.

F- At the second phase of production (at 45 weeks of age), samples are organs (Lower trachea, lung and air sacs).

\section{Samples collection:}

A-Blood from live birds broiler breeders a week prior vaccination.

B- Lower trachea, lung and air sacs from freshly dead broiler breeder are collected over a week as protocol mentioned.

C-Tracheal swabs from progeny collected from each flock as mentioned.

\section{Samples Data}

Table 2.3: Showing data of samples.

\begin{tabular}{|c|c|c|c|c|c|c|c|c|}
\hline \multirow{2}{*}{ Code } & \multirow{2}{*}{ Age/W } & \multirow{2}{*}{ Breed } & \multicolumn{2}{|c|}{ No of birds } & \multirow{2}{*}{ Area } & \multirow{2}{*}{$\begin{array}{c}\text { No. of } \\
\text { samples }\end{array}$} & \multirow{2}{*}{$\begin{array}{l}\text { Type of } \\
\text { samples }\end{array}$} & \multirow{2}{*}{ NOTES } \\
\hline & & & 9 & $\hat{0}$ & & & & \\
\hline ATS 1 & 3 & cobb & 19850 & 2980 & $\begin{array}{l}\text { Alex. Desert } \\
\text { road }\end{array}$ & 20 & Blood & \\
\hline ATS 2 & 10 & cobb & 19680 & 2950 & $\begin{array}{c}\text { Alex. Desert } \\
\text { road }\end{array}$ & 30 & LT,L,AS,O & \\
\hline ATS 3 & 20 & cobb & 19450 & 2920 & $\begin{array}{l}\text { Alex. Desert } \\
\text { road }\end{array}$ & 35 & LT,L,AS,O & \\
\hline ATS 4 & 30 & cobb & 18600 & 2780 & $\begin{array}{l}\text { Alex. Desert } \\
\text { road } \\
\end{array}$ & 38 & LT,L,AS,O & \\
\hline ATS 5 & 30 & cobb & & & $\begin{array}{l}\text { Alex. Desert } \\
\text { road }\end{array}$ & 20 & TS & $\begin{array}{l}\text { From progeny } \\
\text { day old }\end{array}$ \\
\hline ATS 6 & 45 & cobb & 18200 & 2690 & $\begin{array}{c}\text { Alex. Desert } \\
\text { road }\end{array}$ & 42 & LT,L,AS,O & \\
\hline ATS 7 & 48 & cobb & 18100 & 2675 & $\begin{array}{l}\text { Alex. Desert } \\
\text { road }\end{array}$ & 33 & LT,L,AS,O & \\
\hline BTS 1 & 5 & cobb & 29700 & 4350 & Sharqya & 30 & Blood & \\
\hline BTS 2 & 10 & cobb & 29500 & 4250 & Sharqya & 38 & LT,L,AS,O & \\
\hline BTS 3 & 20 & cobb & 29200 & 4180 & Sharqya & 45 & LT,L,AS,O & \\
\hline BTS 4 & 30 & Cobb & 28080 & 4080 & Sharqya & 50 & $\mathrm{LT}, \mathrm{L}, \mathrm{AS}, \mathrm{O}$ & \\
\hline BTS 5 & 30 & cobb & & & Sharqya & 20 & $\mathrm{TS}$ & $\begin{array}{c}\text { From progeny } \\
\text { day old }\end{array}$ \\
\hline BTS 6 & 45 & cobb & 27200 & 3900 & Sharqya & 55 & $\mathrm{LT}, \mathrm{L}, \mathrm{AS}, \mathrm{O}$ & \\
\hline CTS 1 & 2 & cobb & 19900 & 2800 & Dakhlia & 20 & Blood & \\
\hline CTS 2 & 10 & cobb & 19750 & 2750 & Dakhlia & 28 & LT,L,AS,O & \\
\hline CTS 3 & 20 & cobb & 19500 & 2700 & Dakhlia & 30 & LT,L,AS,O & \\
\hline CTS 4 & 30 & cobb & 18250 & 2600 & Dakhlia & 35 & $\mathrm{LT}, \mathrm{L}, \mathrm{AS}, \mathrm{O}$ & \\
\hline CTS 5 & 30 & cobb & & & Dakhlia & 20 & $\mathrm{TS}$ & $\begin{array}{c}\text { From progeny } \\
\text { day old }\end{array}$ \\
\hline CTS 6 & 45 & cobb & 17600 & 2500 & Dakhlia & 40 & LT,L,AS,O & \\
\hline
\end{tabular}

$\mathrm{LT}=$ Lower tracheal part of freshly dead, L=Lung, AS =Air sac, O=Ovaries, TS= Tracheal swab.

\section{Samples transport and storage}

A-Blood from live bird's broiler breeders were collected and transported in ice box and stored in refrigerator.

B-Samples are collected daily during aweek from freshly dead and transported in ice box and stored in freezer

C-Tracheal swabs from progeny were collected and transported in ice box and stored in freezer.

ELISA (Enzyme-linked immunosorbent assay)

Were performed to check Mycoplasma gallisepticum 
antibodies before vaccination of flocks with TS-11 live vaccine (VAXSAFE MG, BIOPROPERITIES $®$ ) using Biochek ${ }^{\circledR}$ Enzyme-linked Immunosorbent Assay (ELISA) for poultry were used as a standardized kit. As manufacturer recommendations.

Real time Polymerase Chain Reaction (real time

\section{PCR) Technique}

Using pooling strategy (8-12 samples were pooled together in one tube), RNeasy Mini Kit (Qiagen, Valencia, CA, USA) protocol. primers and the probe described as below:

Table 2-4: Showing the primers and probes used in real time PCR.

\begin{tabular}{ccc}
\hline Primers & Primer 5'-3' & References \\
\hline MGLPU26-F & 5'-CTA GAG GGT TGG ACA GTT ATG - 3' & Callison et al., 2006 \\
\cline { 1 - 2 } MGLP164-R & 5'-GCT GCA CTA AAT GAT ACG TCA AA - 3' & \\
\cline { 1 - 2 } MGLP-P & 5'-FAM) -CAGTCATTAACA ACT TAC CAC CAG AAT CTG - & \\
(MGB) - 3' & \\
\hline
\end{tabular}

\section{RESULTS}

Table 3-1: Showing Elisa results.

\begin{tabular}{ccc}
\hline Code & Elisa Results & NOTES \\
\hline ATS 1 & Negative & \\
\hline BTS 1 & Negative & \\
\hline CTS 1 & Negative & \\
\hline
\end{tabular}

Table 3-2: Showing PCR results.

\begin{tabular}{lll}
\hline Code & Real time PCR Results & NOTES \\
\hline ATS 2 & Negative & \\
\hline ATS 3 & Negative & From progeny \\
\hline ATS 4 & Negative & \\
\hline ATS 5 & Negative & \\
\hline ATS 6 & Positive & \\
\hline ATS 7 & Negative & From progeny \\
\hline BTS 2 & Negative & \\
\hline BTS 3 & Negative & \\
\hline BTS 4 & Negative & \\
\hline BTS 5 & Negative & \\
\hline BTS 6 & Negative & From progeny \\
\hline CTS 2 & Negative & \\
\hline CTS 3 & Negative & Negative \\
\hline CTS 4 & Negative & \\
\hline CTS 5 & Negative & \\
\hline CTS 6 &
\end{tabular}

Table 3-3: Performance monitoring results.

\begin{tabular}{cccccccc}
\hline & ATS & AO & BTS & BO & CTS & CO & NOTES \\
\hline production peak \% & 85.5 & 81.7 & 87 & 80 & 86.4 & 79.2 \\
\hline $\begin{array}{c}\text { Perseverance on production } \\
\text { peak (weeks) }\end{array}$ & 9 & 5 & 11 & 6 & 11 & $\begin{array}{c}\text { Not reach } \\
80 \%\end{array}$ \\
\hline Cumulative Hatchability \% & 85.6 & 78 & 84.6 & 79.3 & 84.4 & 76 \\
\hline Total eggs / hen & 181.2 & 173 & 179.2 & 168 & 179 & 161 \\
\hline Mortality \% & 10.3 & 14 & 9.2 & 12.3 & 10.25 & 12.4 \\
\hline
\end{tabular}




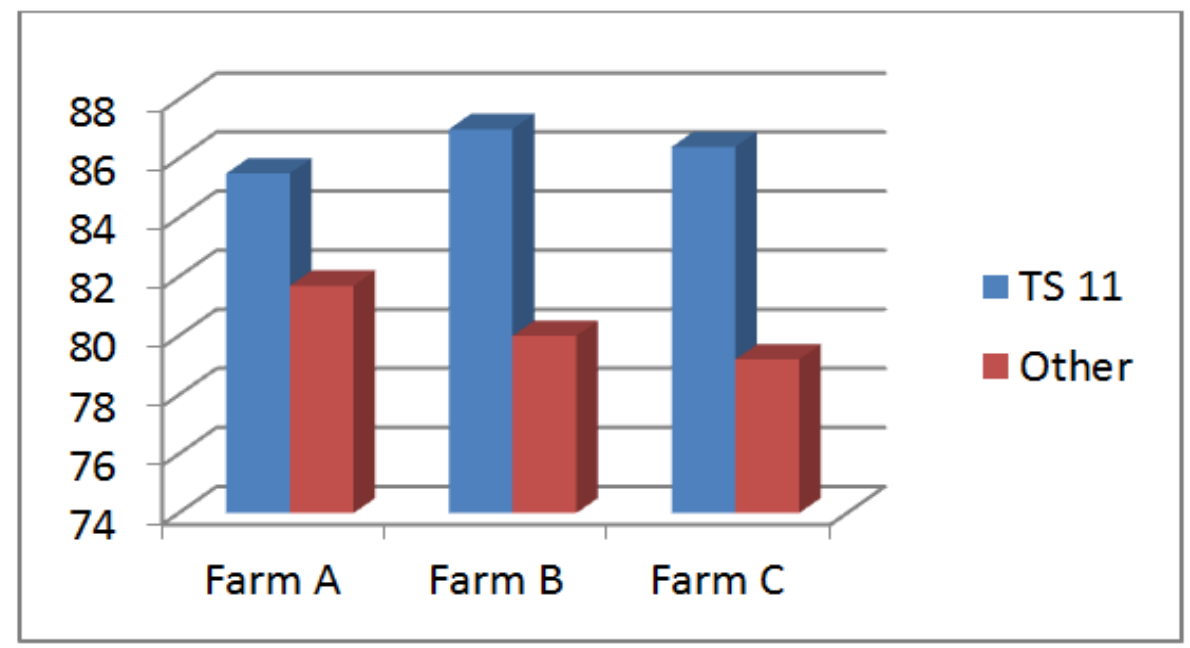

Figure 3.1: Showing production peak\% in the six flocks.

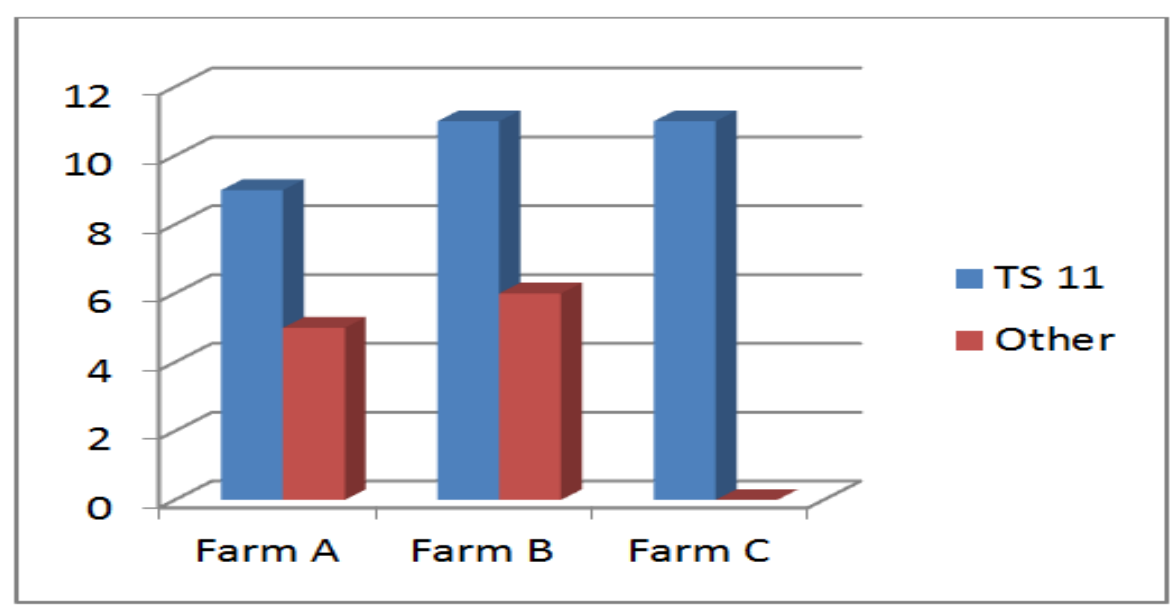

Figure 3.2: Showing perseverance on peak of the six flocks.

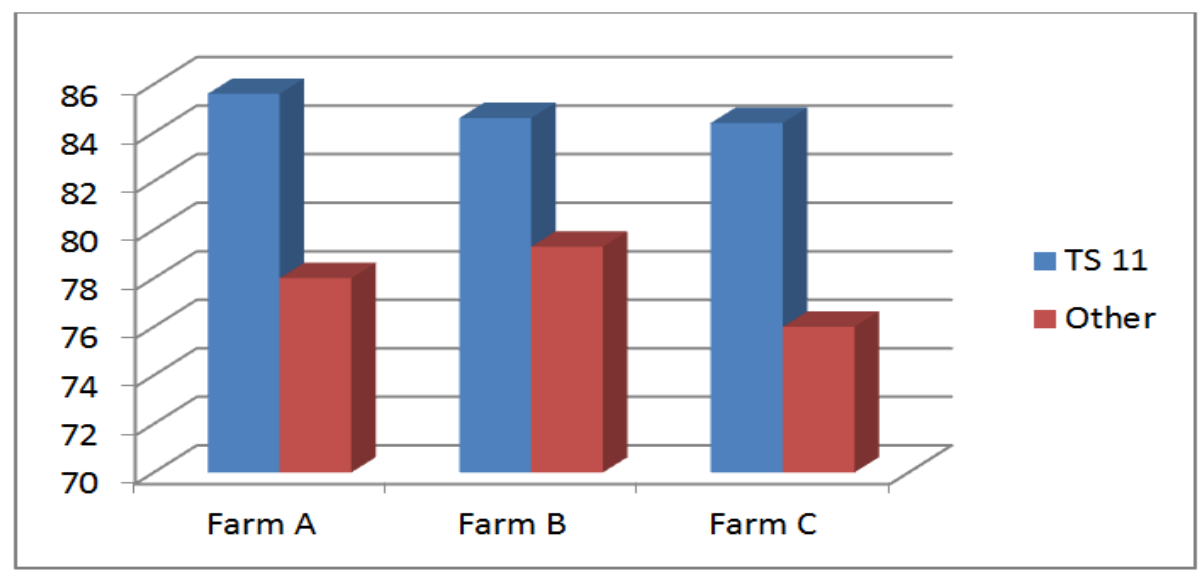

Figure 3.3: Showing cumulative hatchability $\%$ in the six flocks. 


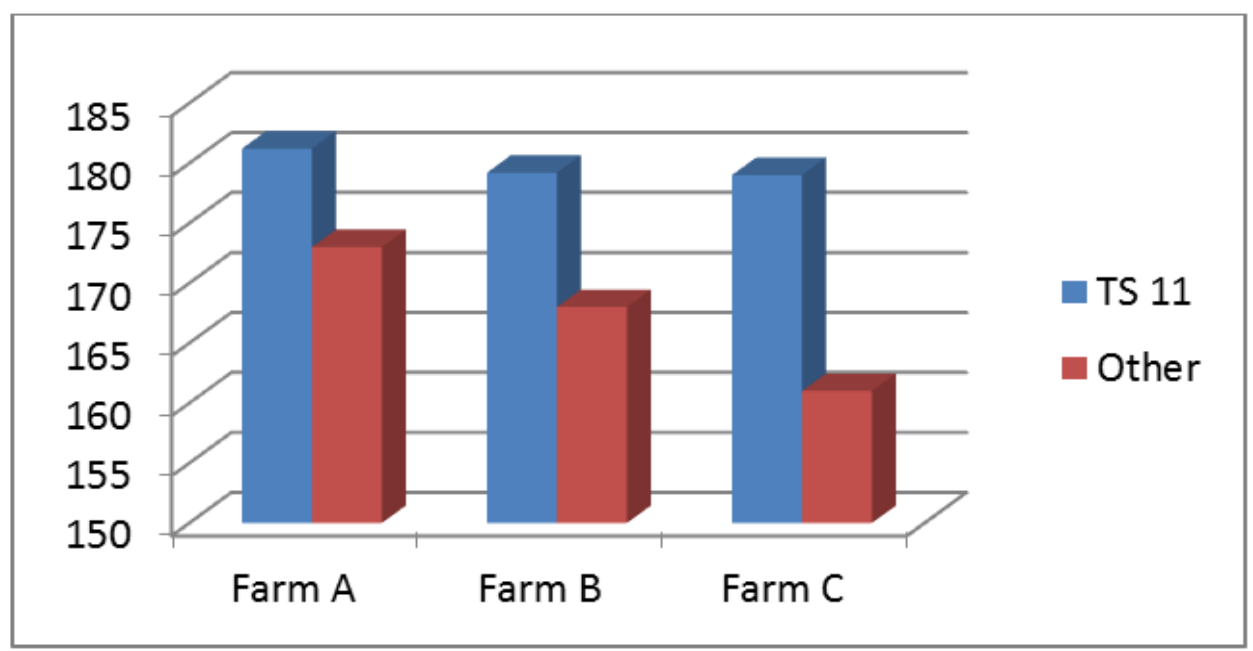

Figure 3.4: Showing total eggs / hen in the six flocks.

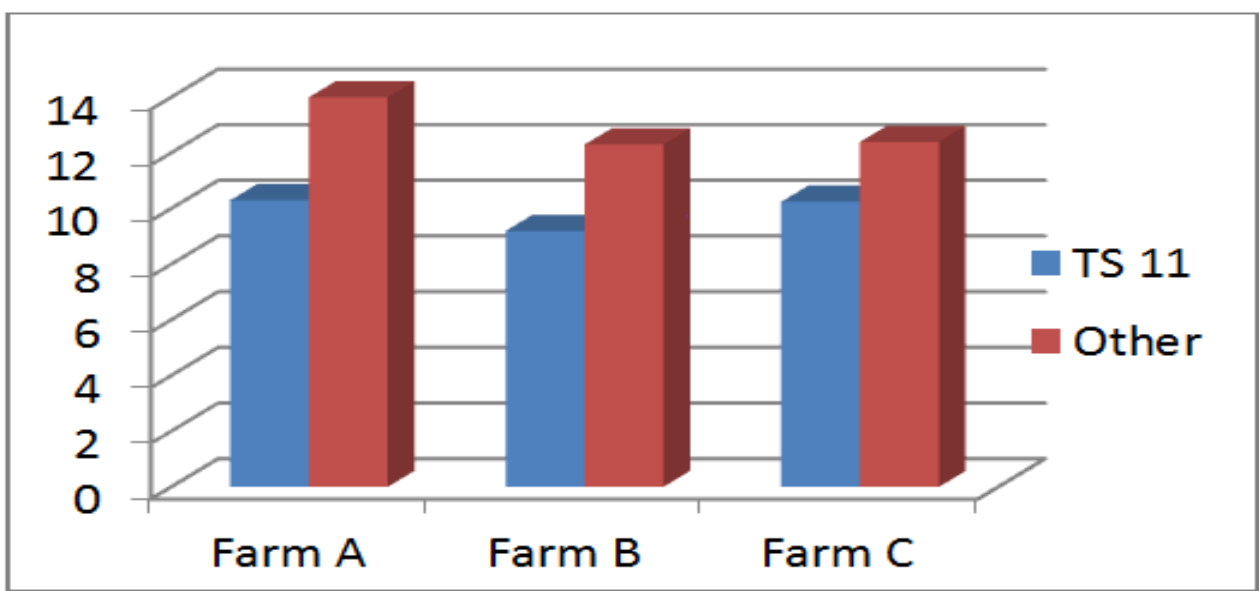

Figure 3.5: Showing Mortality $\%$ in the six flocks.

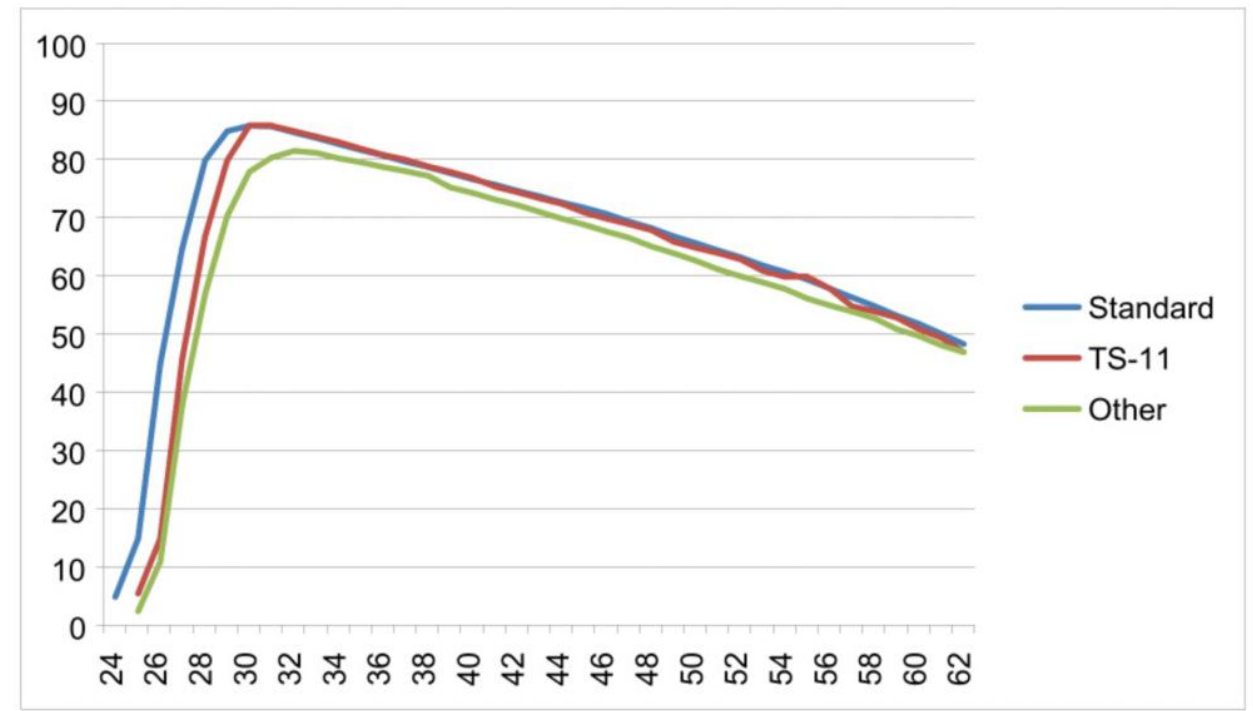

Figure 3-6: Comparison production \% per week between two flocks in farm A with standard and each other: 


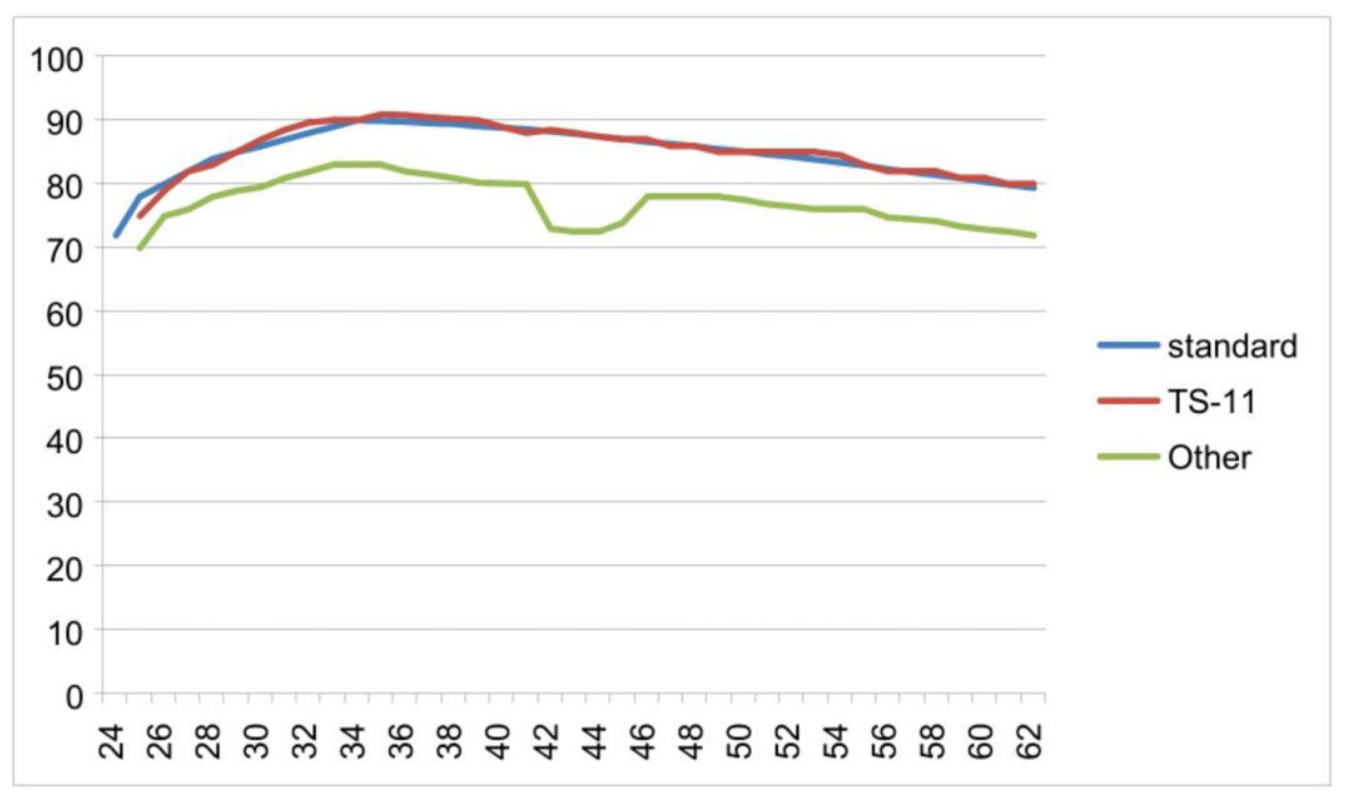

Figure 3-7: Comparison hatchability \% per week between two flocks in farm A with standard and each other:

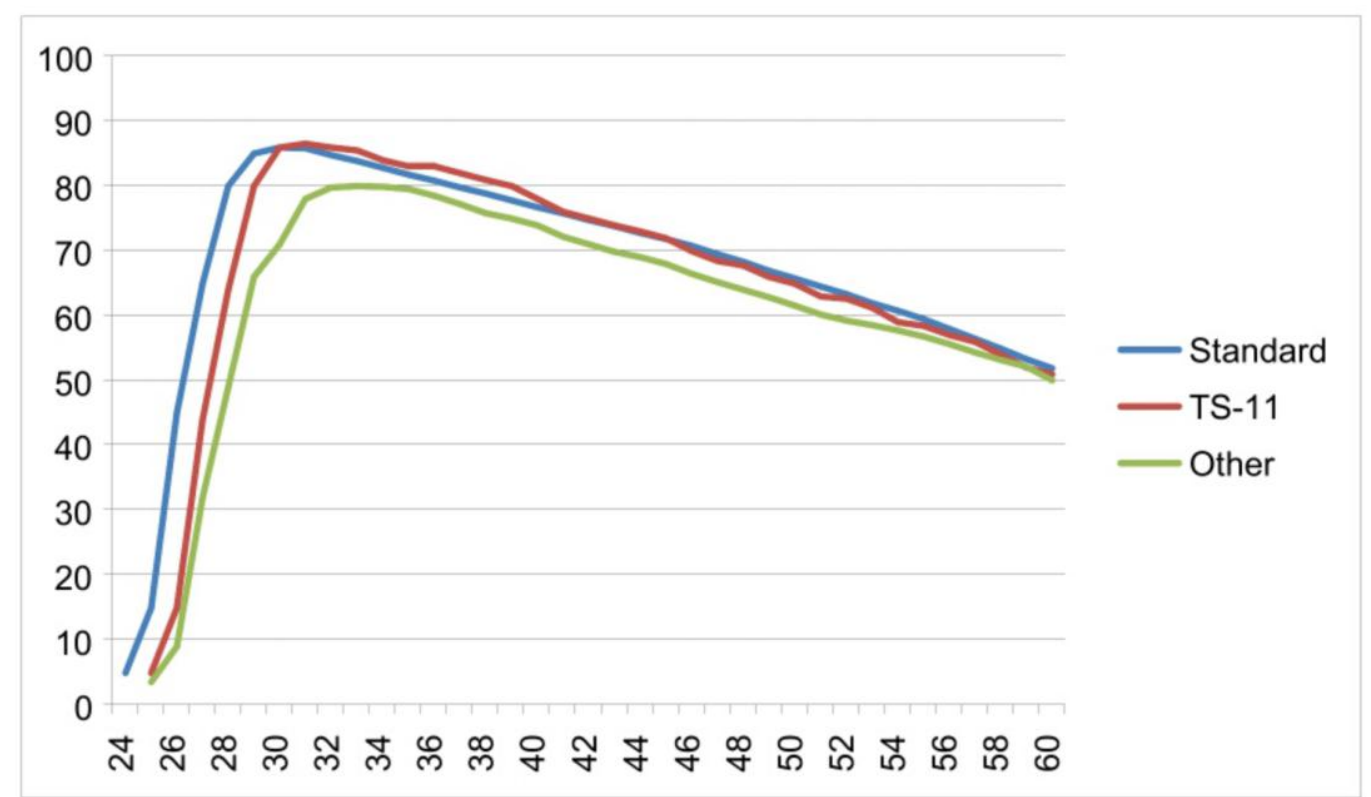

Figure 3-8: Comparison production \% per week between tow flocks in farm B with standard and each other: 


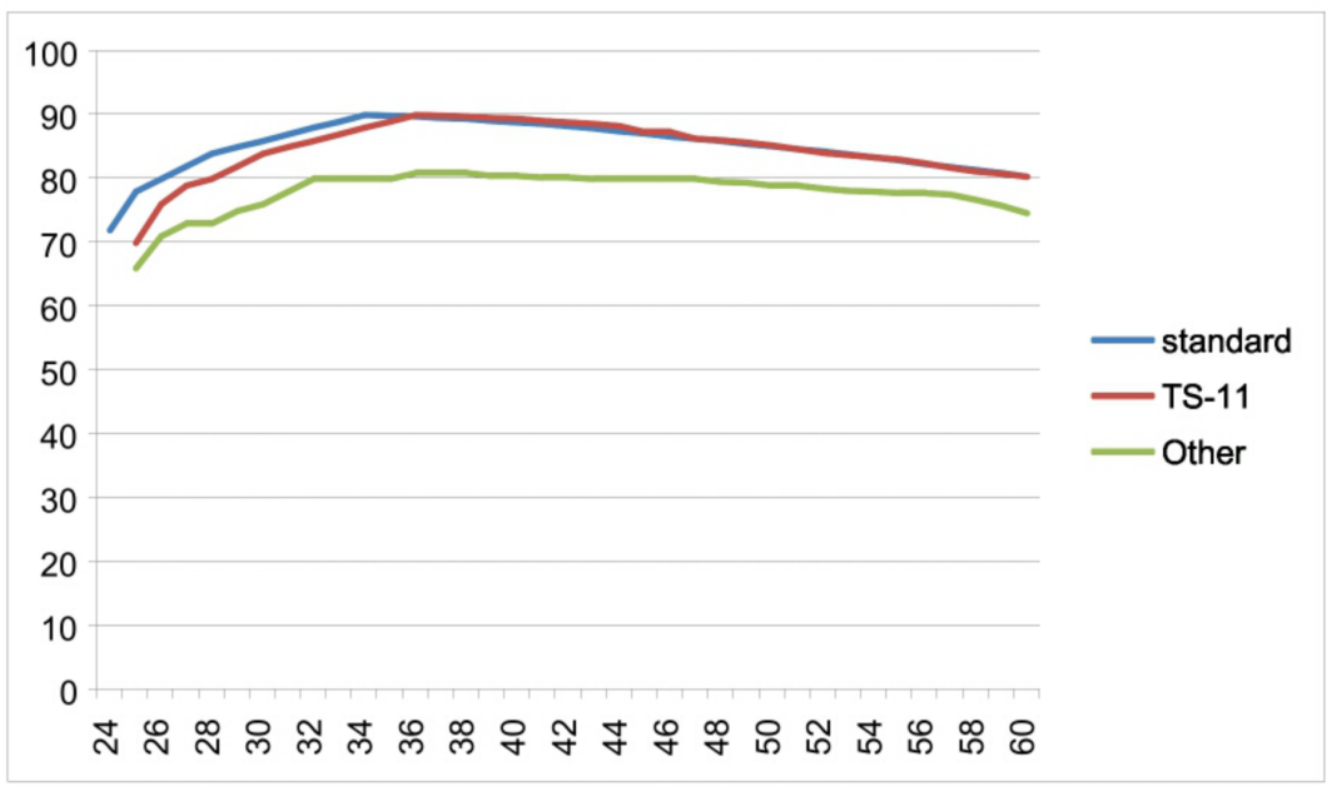

Figure 3-9: Comparison hatchability \% per week between two flocks in farm B with standard and each other:

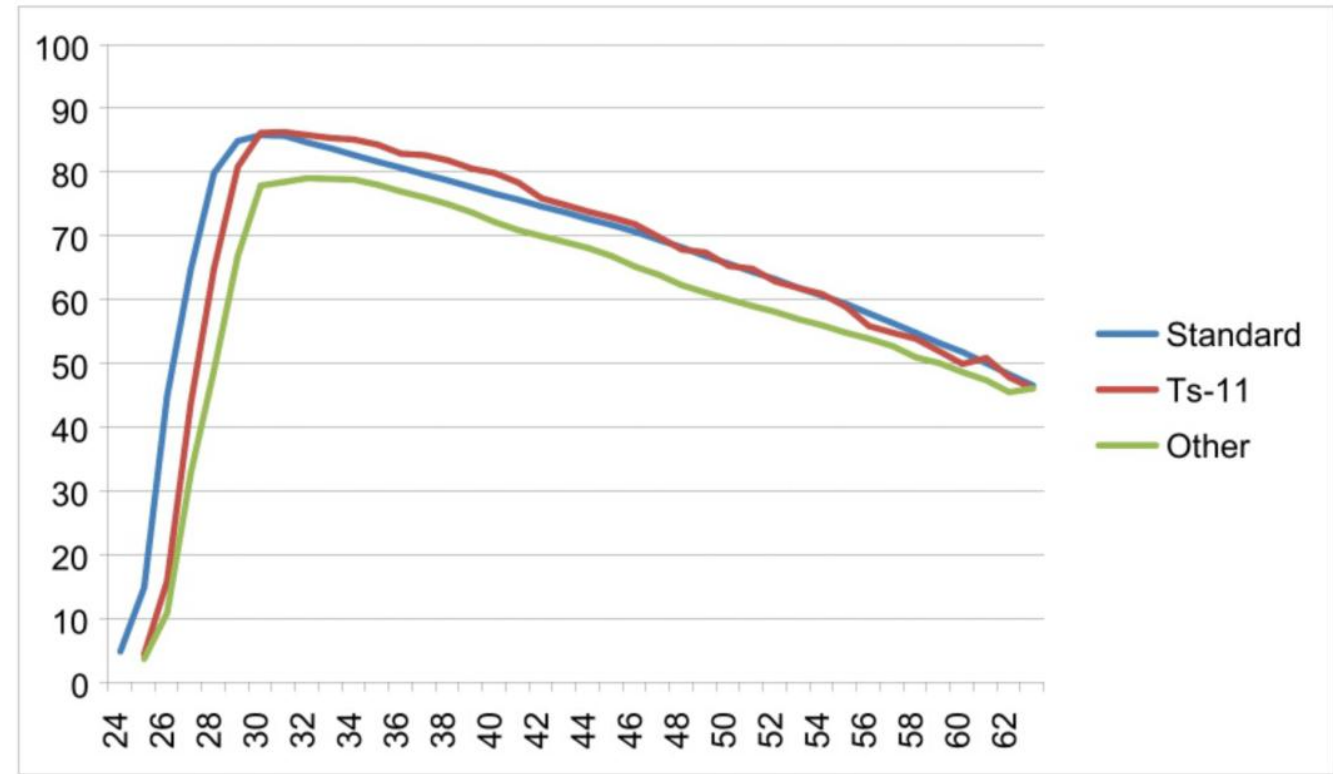

Figure 3-10: Comparison production \% per week between two flocks in farm $\mathrm{C}$ with standard and each other: 


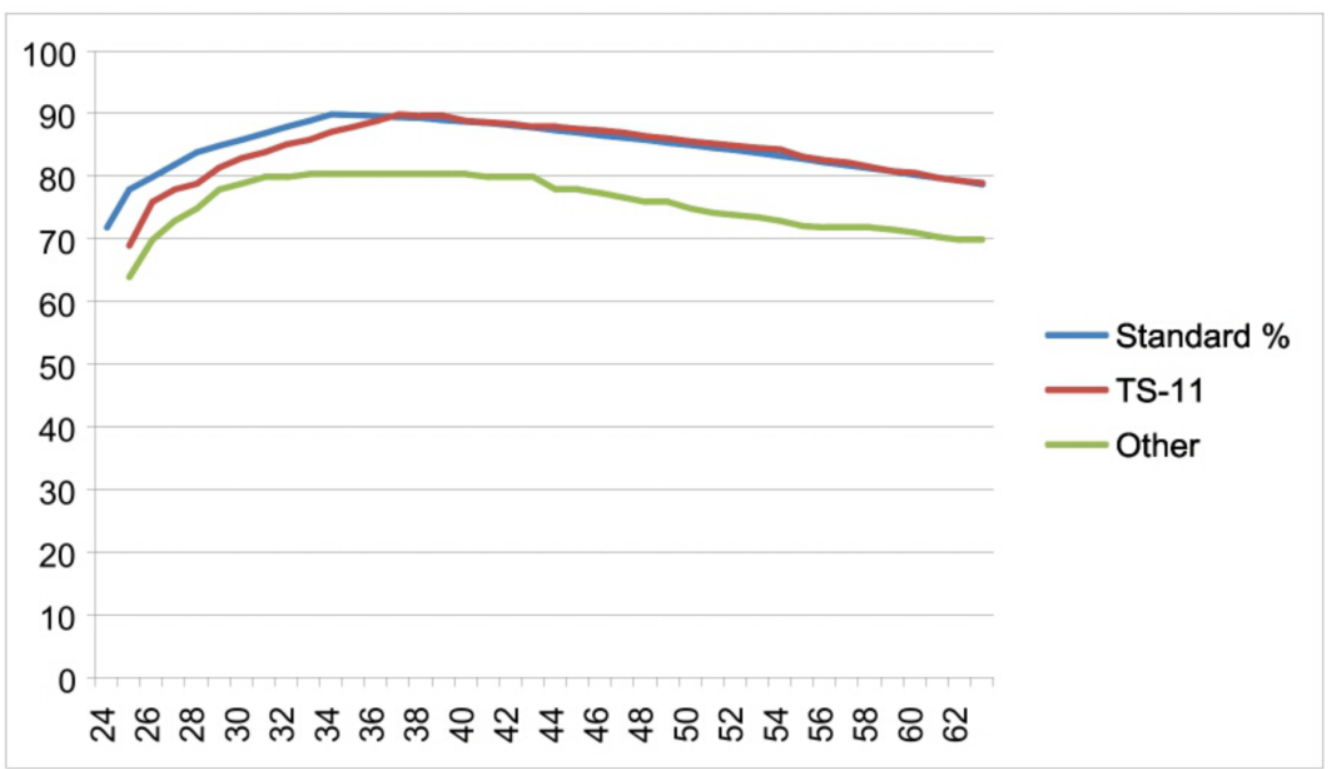

Figure 3-11: Comparison hatchability \% per week between two flocks in farm C with standard and each other:

\section{DISCUSSION}

Ts-11 vaccine has been determined as low virulent or avirulent strain and has extensively been used as atoll for the control of Mycoplasma gallisepticum since its introduction in Australia 20 years ago (Bioproperities®, 2005). And has been showed to provide protection against respiratory disease, egg production losses and vertical transmission associated with virulent Mycoplasma gallisepticum infection (whithear et al., 1990a; Abd- elmotelib and Kleven, 1993; Whithear 1996; Barbour et al., 2000).

The majority of laboratory studies showed that vaccinated chickens with ts-11 strain have been able to resist challenge with virulent $M$. gallisepticum administered by direct air sac inoculation, aerosol (Whithear et al., 1990a) or intra-tracheal inoculation (K.G. Whithear, 1996). Protection against respiratory signs persists up to at least 40 weeks after vaccination (Whithear and Harrigan, 1993), and was significantly greater than the protective immunity elicited by bacterin (Whithear and Harrigan, 1994). In experimental challenge studies, the ts- 11 strain almost invariably provides solid protection against the development of tracheal and nasal sinus lesions but protection against the development of air sac lesions is less consistent (Whithear and Harrigan, 1993).

A comparative study by Abd-El-Motelib and Kleven (1993) showed that $F$ strain provided higher protection against the development of air sac lesions following aerosol challenge than that of the milder vaccine strains 6/85 and ts-11. However, using inoculation into the infraorbital sinuses as a method of challenge, ts-11 gave a higher protection than that of both $\mathrm{F}$ and $6 / 85$ strains.

Our study results showed the ability of Ts-11 vaccine to protect chickens from natural infection of $\mathrm{MG}$ till 45 weeks old (results of PCR as shown in table 3-2) and show the efficacy of Ts-11 in comparison with other programs used previously in these farms for MG control. Only one sample in farm (A) was positive and when repeating sampling and PCR test at 48 weeks old gave negative result which explaining exposuring to challenge but no infection occurs. This is in agreement with and ensure results of whithear et al. (1990a); Abd- elmotelib, Kleven, (1993); Whithear (1996). This reported a variable efficacy of Ts-11 in challenge experiments.

Vaccination with $\mathrm{F}$ strain significantly reduced the rate of and delayed, but did not eliminate, egg transmission of M. gallisepticum in hens challenged by aerosol (Glisson and Keleven, 1984). Similarly, ts11 strain reduced but did not prevent egg transmission in hens challenged by direct inoculation of virulent $M$. gallisepticum into the abdominal air sacs (K.G. Whithear, 1996). Elgazzar et al. (2011) report that Ts11 vaccine was transmitted to egg through ovaries. In this study results of examination of tracheal swabs of day old chicks produced from vaccinated breeders of all three farms were negative for MG filed or vaccine strain (results of PCR are shown in table 3-2) and this revealed the ability of Ts-11 to prevent vertical transmission of MG to offspring our result is in agreement and ensures results of (Whithear 1996 and 
Barbour et al., 2000). And disagree these (Elgazzar et al., 2011).

A mathematical model was designed to evaluate the effect of Mycoplasma gallisepticum live vaccines on preventing drops in egg production in layers (Evans and Hafez, 1992) Hens vaccinated with strain 6/85 produced significantly fewer $(\mathrm{P}<0.05)$ eggs than those vaccinated with $F$ strain in the periods immediately after challenge (i.e. deterioration and early recovery phases), but significantly more $(\mathrm{P}<$ $0.05)$ in the late recovery phase. Pullets vaccinated with ts-11 produced 41.3 eggs over a seven-week period after air sac inoculation with virulent $\mathrm{M}$. gallisepticum, compared with 25.8 eggs $(\mathrm{P}<0.01)$ produced by unvaccinated hens. There was no significant difference in the number of eggs laid by vaccinated hens after challenge and those laid by a group of unchallenged controls (Whithear et al., 1990). In six field trials conducted prior to the commercial introduction of ts-11 into Australia, the mean production of vaccinated flocks was $219.6 \mathrm{eggs}$ per hen housed to 65 weeks of age, compared with 211.9 eggs for unvaccinated groups $(\mathrm{P}<0.01)$ (Whithear and Harrigan, 1994).

In this study Egg production and hatchability results specially till 45 weeks old was better than ideal curves and in comparison with the previous flocks which use other programs and were complained from infection the results are significantly differ.

Total eggs / hen in farm A using other program was 173 and when using TS_11, it reached 181.2 also in farm B it was 168 and reach 179.2 and in farm C it was 161 and reached 179 that was significantly more ( $\mathrm{P}<0.05)$. These results ensure results of (whithear et al., 1990a; Abd- elmotelib and Kleven, 1993; Whithear, 1996).

Our study shows the ability of Ts-11 to protect chickens from natural infection of $\mathrm{MG}$, prevent vertical transmission to the progeny and also keeping egg production and hatchability not affected.

Ts-11 vaccine is recommended for using in highly endemic areas and considered the safest and most efficient live vaccine for controlling of MG infection where total eradication is considered impossible.

\section{REFERENCES}

AbdEl-motelib, T.Y. and Kleven, S.H. (1993): Acomparative study of mycoplasma gallisepticum vaccines in young chickens. Avian Dis. 37: 981-987.

Barbour, EK.; Hamadeh, SK. and Eidt, A. (2000): Infection and immunity in broiler chicken breeders vaccinated with a temperature- sensitive mutant of Mycoplasma gallisepticum and impact on performance of offspring. Poult. Sci. 79 (12): 1730-1735.

Callison, SA.; Riblet, SM.; Sun, S.; Ikuta, N.; Hilt, D.; Leiting, V.; Keleven, SH.; Suarez, DL. and Garcia, M. (2006): Development and validation of a real-time taqman polymerase chain reaction assay for detection of mycoplasma gallisepticum in naturally infected birds. Avian Dis. 50: 537-544.

Elgazzar, M.; laibinis, V.A. and Ferguson-Noel, N. (2011): Characterization of TS-11 like mycoplasma gallisepticum isolate from commercial broiler chickens. Avian Dis.55: 569-574.

Evans, R.D. and Hafez, Y.S. (1992): Evaluation of a Mycoplasma gallisepticum strain exhibiting reduced virulence for prevention and control of poultry mycoplasmosis. Avian Diseases, 36: 197-201.

Glisson, J.R. and Kleven, S.H. (1984): Mycoplasma gallisepticum vaccination: Effects on egg transmission and egg production. Avian Diseases, 28: 406-415.

Levisohn, S. and Dykstra, M.J. (1987): A quantitative study of single and infection of the chicken trachea by Mycoplasma gallisepticum. Avian Diseases, 31: 1-12.

LEY, D.H. (2003): $\quad$ Mycoplasma gallisepticuminfection. In Diseases of Poultry (11th ed. Swayne, D. E.) Iowa State University Press, Ames, Iowa, pp. 722-744.

LEY, D.H. (2008): Mycoplasma gallisepticuminfection. In Diseases of Poultry (12th ed. Swayne, D. E.) Iowa State University Press, Ames, Iowa, pp. 807-834.

Pakpinyo, S.; Limstanun, A.; Sangthongdang, K.; Paniago, M. and Soares, R. (2015): Protection against mycoplasma gallisepticum in layers immunized with recombinant fowl poxvirus vaccine followed by live $F$ strain vaccine. Thai J vet. Med. 45(2):197-204.

Whithear, K.G. (1996): Control of avian mycoplasmoses by vaccination. Rev. sci. tech. Off. int. Epiz., 15: 1527-1553.

Whithear, K.G. and Harrigan, K.E. (1993): Duration of immunity elicited by strain TS-11 (Vaxsafe MG TM) mycoplasma gallisepticum vaccine 10th international congress of the world poultry association, 186.

Whithear, K.G. and Harrigan, K.E. (1994): Living with mycoplasma vaccines, 9 theuropean poultry conference. world poultry science association, 285-287.

Whithear, K.G.; Soeripto, Harrigan, K.E. and Ghiocas, E. (1990a): Immunogenicity of a temperature sensitive mutant Mycoplasma gallisepticum vaccine. Australian Veterinary Journal, 67: 168-174.

Whithear, K.G.; Soeripto, Harrigan, K.E. and Ghiocas, E. (1990b): Safety of temperature 
sensitive mutant Mycoplasma gallisepticum vaccine. Australian Veterinary Journal, 67: 159-165.

Yagihashi, T.; Nunaya, T.; Sannai, S. and TaJima, M.
(1992): Comparison of immunity induced with a mycoplasma gallisepticumbacterin between high- and low- responder lines of chickens. Avain Dis. 36: 125-133.

\section{متابعة قطعان أمهات التسمين والكتاكيت الناتجة منها لعدوى الميكويلازما جاليسيبتكم وأداء القطعان

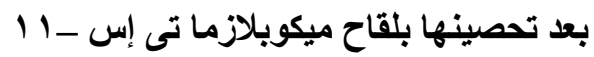$$
\text { هيثم محمد جمال ، أحمد إبراهيم/ احعد ، نبيلة محمود محمد عثمان }
$$ \\ E-mail: haytham.gamal@ift-online.com \\ Assiut University web-site: www.aun.edu.eg}

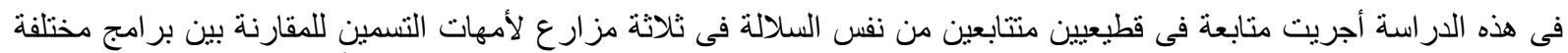

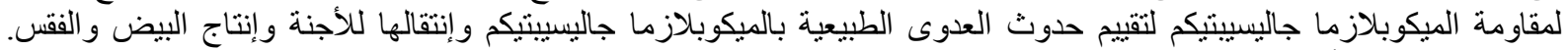

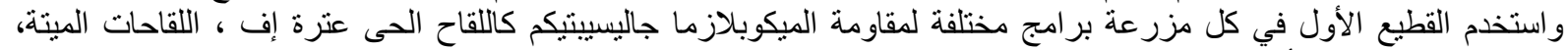

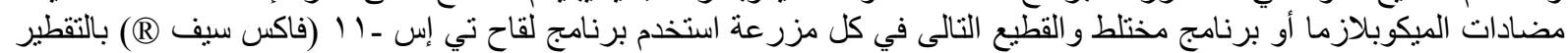

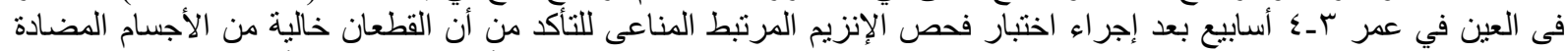

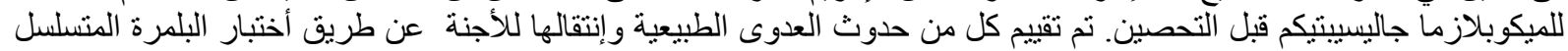

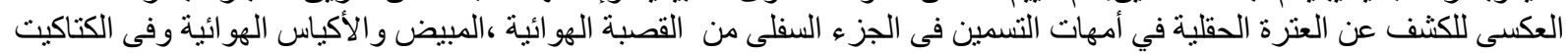

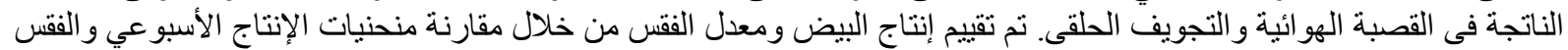

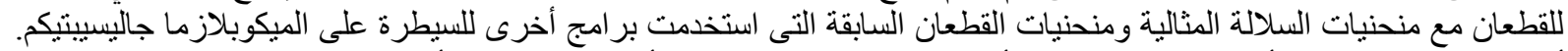

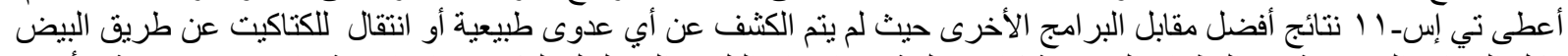

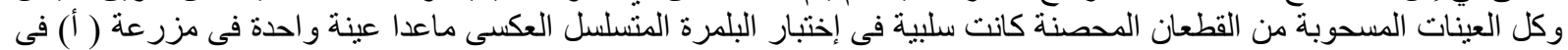

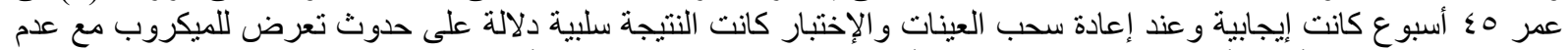

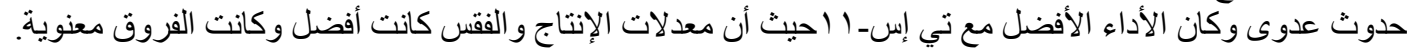

